\title{
Traumatic Vulvar Epithelial Inclusion Cysts Following Female Genital Mutilation (FGM)
}

\author{
Traumatische Plattenepithelzyste der Vulva nach weiblicher \\ Genitalverstümmlung (FGM)
}

Authors

Affiliations
B. Mack-Detlefsen ${ }^{1}$, S. Banaschak ${ }^{2}$, T. M. Boemers ${ }^{1}$

${ }^{1}$ Pediatric Surgery and Urology, Kinderkrankenhaus Amsterdamer Straße, Cologne

${ }^{2}$ Department of Forensic Medicine, University Clinic of Cologne, Cologne
Key words

- adolescence

- benign tumours of the vulva

- dysuria

Schlüsselwörter

- Adoleszenz

- benigne Vulvatumoren

- Dysurie

Deutsche Version unter: www.thieme-connect.de/ ejournals/gebfra $\begin{array}{lr}\text { received } & 10.2 .2015 \\ \text { revised } & 23.6 .2015 \\ \text { accepted } & 25.6 .2015\end{array}$

Bibliography

DOI http://dx.doi.org/

10.1055/s-0035-1557862

Geburtsh Frauenheilk 2015; 75 : 945-948 @ Georg Thieme Verlag KG Stuttgart · New York ISSN 0016-5751

\section{Correspondence}

Dr. Birte Mack-Detlefsen

Kinderkrankenhaus

Amsterdamer Straße

Pediatric Surgery and Urology

Amsterdamer Straße 59

50735 Cologne

Birte.D@gmx.net

\section{Abstract}

$\nabla$

Background: Female genital mutilation (FGM) occurs mainly in Africa, parts of the Arabian Peninsula and parts of Asia. It is commonly associated with acute complications as well as diverse late/ delayed complications. One of the most common of these late complications is progressively enlarging painless cysts of the vulva.

Case Report: An 8-year-old girl from Eritrea presented to our paediatric emergency department with a progressively enlarging mass of the vulva. She had undergone a clitoridectomy and partial removal of the labia minora as an infant in Eritrea. We performed surgical excision of the cyst and reconstruction of the labia. Histology showed a traumatic squamous epithelial inclusion cyst of the vulva.

Conclusion: Epithelial or dermoid cysts of the vulva following FGM are extremely rare. Symptoms often require surgical intervention. Through increasing migration, more girls and female youths with FGM are likely to present to practices and hospitals in Germany. Thus increased knowledge and awareness of the medical complications of FGM and their treatment will be necessary in years to come.

\section{Introduction \\ $\nabla$}

Female genital mutilation (FGM) or female genital circumcision (FGC) occurs mainly in Africa, parts of the Arabian Peninsula and parts of Asia. The central, western and north-eastern regions of Africa including countries such as Somalia, Sierra Leone, Mali, Guinea and the Sudan are most affected [1]. The precise origins of FGM are un-

\section{Zusammenfassung \\ $\nabla$}

Hintergrund: Die weibliche Genitalverstümmelung (FGM) kommt vor allem in Afrika, auf Teilen der arabischen Halbinsel und in Teilen Asiens vor. Diese Verstümmelung ist oft mit akuten Komplikationen und vielfältigen Spätfolgen verbunden. Eine der häufigsten Spätfolgen sind schmerzlose, größenprogrediente Zysten im Bereich der Vulva. Fallbeispiel: Ein 8-jähriges Mädchen aus Eritrea stellte sich in unserer kinderchirurgischen Notfallambulanz vor mit einer größenprogredienten Raumforderung im Bereich der Vulva. In Eritrea war im Säuglingsalter eine Klitoridektomie mit partieller Entfernung der kleinen Labien durchgeführt worden. Es erfolgte die chirurgische Exzision der Zyste und die Labienrekonstruktion. Histologisch zeigte sich eine traumatische Plattenepithelzyste der Vulva.

Schlussfolgerung: Plattenepithelzysten bzw. Dermoidzysten im Bereich der Vulva nach FGM kommen häufig vor. Die durch die Zysten und Dermoide verursachten Beschwerden erfordern oftmals eine chirurgische Intervention. Durch die zunehmende Migration nach Deutschland werden sich sicher mehr Mädchen und weibliche Jugendliche mit FGM in den Praxen und Kliniken vorstellen. Daher wird eine Verbreiterung der Kenntnisse der medizinischen Folgen nach FGM und der therapeutischen Konsequenzen in den kommenden Jahren erforderlich sein.

known. Earliest historical evidence is found in a religious text on an Egyptian sarcophagus (approx. 1991-1786 B.C.). The circumcision of a temple maiden is mentioned on a papyrus from the year 163 B.C. First written documentation of FGM, by the Greek geographer Strabo, dates back to the year 25 B.C. [2]. Examinations of Egyptian mummies by an Australian pathologist have shown that infibulation was not carried out. Fur- 
ther written documents originate from the Greek doctors Galen, middle 2nd century A.D., and Aetios, middle 5th-6th century A.D. The surgical method is described in detail in "Book 16" [3]. The work by Aetios is noteworthy for a number of reasons e.g. the exact function of the clitoris was known, FGM was not performed by midwives, and it was performed on girls before marriage. Aetios's work confirmed statements by Strabo. In this context statements made by the Greek doctor Soranus in the 2nd century A.D. "about the finding of a big clitoris and its surgical treatment" are worthy of mention. The original document no longer exists however later adaptions of Soranus by Caelius Aurelius, a doctor from Sicca Veneria in Tunisia in the 5th century A.D., and the Arabic doctor Al-Zahrawi, 11th century A.D. are noteworthy.

More than 120 surgical techniques are described in "Book 6" of the written records of Paul of Aegina, a doctor in Alexandria in the 7th century A.D. Interestingly, the anatomical findings in his patients may be consistent with DSD (developmental sexual disorder).

From the works of Aetios, Galen and Soranus it is important to note that the indication for FGM had medical aspects, e.g. size reduction of an enlarged clitoris. There is only a single text passage from outside of Egypt, by the historian Xanthos from the 5th century B.C. that documents castration equivalent to FGM being performed in a region of modern-day Western Anatolia. There is no written documentation of FGM as a practice of the Islamic religion, or of its occurrence in the Kingdom of Saudi Arabia.

Finally, it is important to note that clitoridectomy was performed in 19th century Europe and the United States of America as treatment for psychiatric illnesses such as "hysteria" and to prevent masturbation [4].

FGM is performed in infants or between the 8th and 12th years of life [5]. There are an estimated 20000 to 40000 women currently living in Germany who have suffered genital mutilation as infants or children [5]. This mutilation is often associated with acute complications and various late complications [6]. One of most common late complications is painless progressively enlarging cysts of the vulva $[6,7]$. They result from entrapment of keratinised squamous epithelium in scarred areas following FGM. Concrements can occasionally form within these cysts $[7,8]$. The treatment of choice is complete surgical cyst excision. We present a case of an 8-year-old girl with a traumatic epithelial inclusion cyst of the vulva.

\section{History}

$\nabla$

An 8-year-old girl from Eritrea presented to our paediatric surgical emergency unit with a progressively enlarging vulvar mass. She had first presented to a practice paediatrician. The patient reported increasing pain on walking/running, progressive obstructive urinary symptoms and intermittent retention. She had had the swelling in her vulvar area for approx. 2 years and it had grown markedly in the preceding months. No other illnesses were known.

Social history: The patient had been living in Germany for 8 months. Her father stated that as a newborn in her homeland, Eritrea, a "ritual circumcision" had been performed on her by a female relative in his absence.

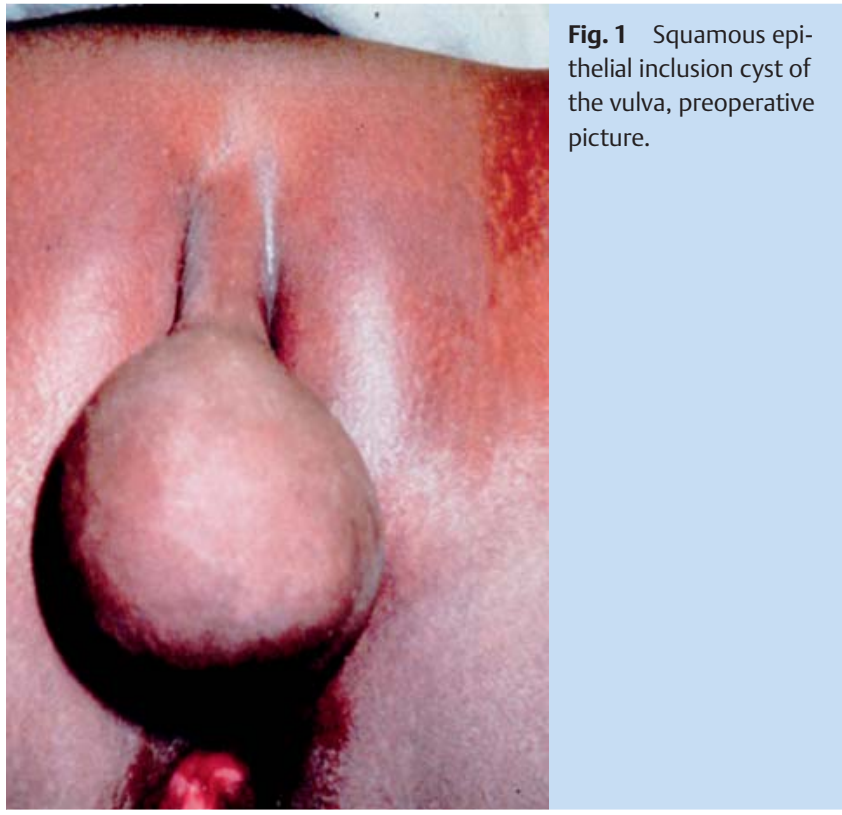

\section{Clinical Examination}

In the area of the clitoris an approx. $4 \times 4 \mathrm{~cm}$ tense, fluctuant mass was noted ( $\bullet$ Fig. 1). Genital findings were otherwise consistent with Type II FGM (WHO classification): clitoridectomy with partial removal of the labia minora. The vaginal orifice had not been closed.

\section{Operative Management \\ $\nabla$}

The patient was admitted for surgical resection of the mass and reconstructive surgery of the labia. Inspection of the genitalia was performed in general anaesthesia. The vaginal orifice and external urethral orifice were normal. In the area of the vulva the $4 \times 4 \mathrm{~cm}$ tense, fluctuant mass was found to be pedunculated on a scar tissue stalk. Vaginoscopy was normal. The tumour, which was filled with a yellowish, gelatinous material, was carefully enucleated after midline diathermic skin incision ( $\boldsymbol{\bullet}$ Fig. 2). Using bipolar forceps it was completely removed on its stalk (peduncle) without perforation ( $\bullet$ Fig. 3). The labia minora were then reconstructed using the two remaining skin flaps and a urinary catheter inserted. Wound management comprised Jelonet gauze and compression. In addition we treated with intravenous cefuroxime and metronidazole.

Histology showed a squamous epithelial cyst of the vulva that was described as "evidently traumatic in nature" by the pathologist (O Fig. 4).

The postoperative period was uneventful and the urinary catheter was removed after a week. Urinary symptoms improved rapidly. The patient, her parents and the surgical team rated the plastic surgical result as very good. To avoid aggravating the patient's feelings of shame photographic documentation was not performed. Child welfare services and a local gynaecologist were involved to assist with future psychosocial and medical care. The responsible police services were notified. In this case there were no legal ramifications for the family, since the FGM occurred 8 years previously in Eritrea and there was no risk of FGM to oth- 


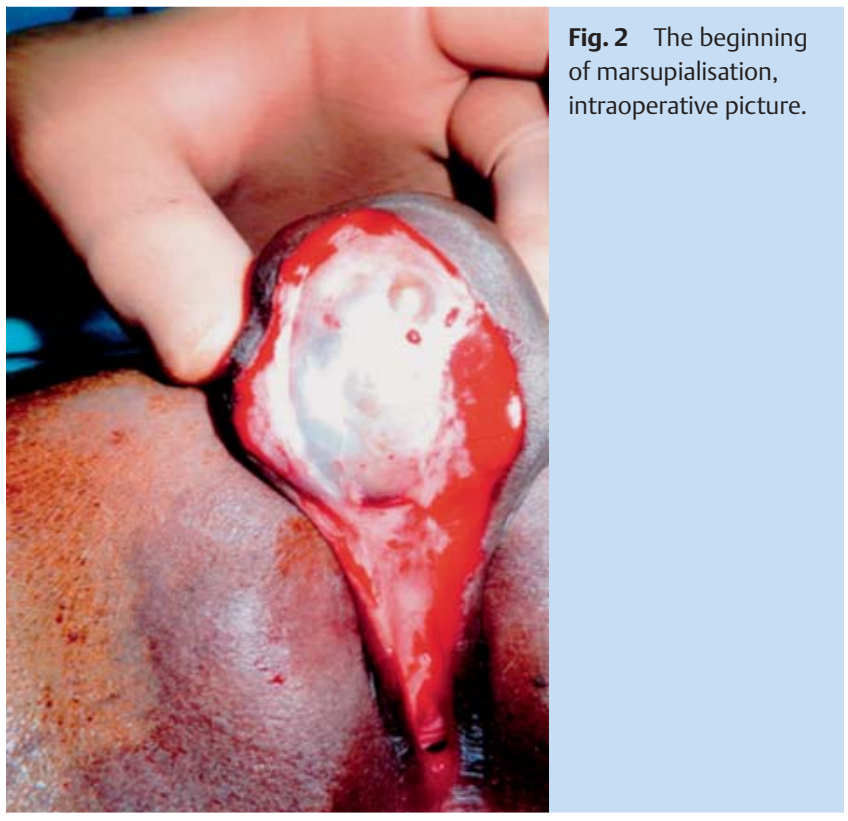

er children in the family in Germany. In Eritrea FGM has been a criminal offence since 31.07.2007 [1,5].

In Germany various legal aspects are elucidated e.g. the abuse of power over vulnerable individuals, abuse of parental responsibility/custodianship or grievous bodily harm are distinguished from threatened FGM in the patient's homeland where e.g. deportation should be prevented $[1,5]$.

\section{Discussion}

$\nabla$

According to WHO estimates, approx. 100 to 140 million women are affected by female genital mutilation worldwide. The WHO classifies FGM into 4 types [1,5,9].

Numerous complications are caused by this mutilating practice. They can be classified as acute or chronic.

Acute complications include local infections that can progress to sepsis. HIV infection has also been described. Urinary symptoms such as dysuria and acute urinary retention, particularly following infibulation, are listed by Teufel et al. [10] and other authors. Injury to nearby organs e.g. urethra, bladder and anal sphincter have been described. Fractures of the femur and clavicle have been reported due to girls being forcefully immobilized. One of the most common acute complications is bleeding, often with dramatic consequences $[5,11]$.

Chronic complications comprise protracted wound healing and ascending infection such as urethritis and vaginitis. Vaginal stenosis and infertility have been described. Dysmenorrhoea and menorrhagia occur after menarche.

The complication in our case report is classified with delayed complications that also include keloid formation or chronic abscess in the area of scar tissue, neurinoma (amputation neurinoma) and dermoid cyst. Further complications can occur in pregnancy and labour e.g. increased bleeding, local wound dehiscence, protracted labour, perineal infections and fistulae (vesicoand rectovaginal) $[5,10]$.

In their meta-analysis Rigmor et al. showed that women who had undergone FGM were at increased risk of dyspareunia, reduced libido and reduced sexual satisfaction compared to controls

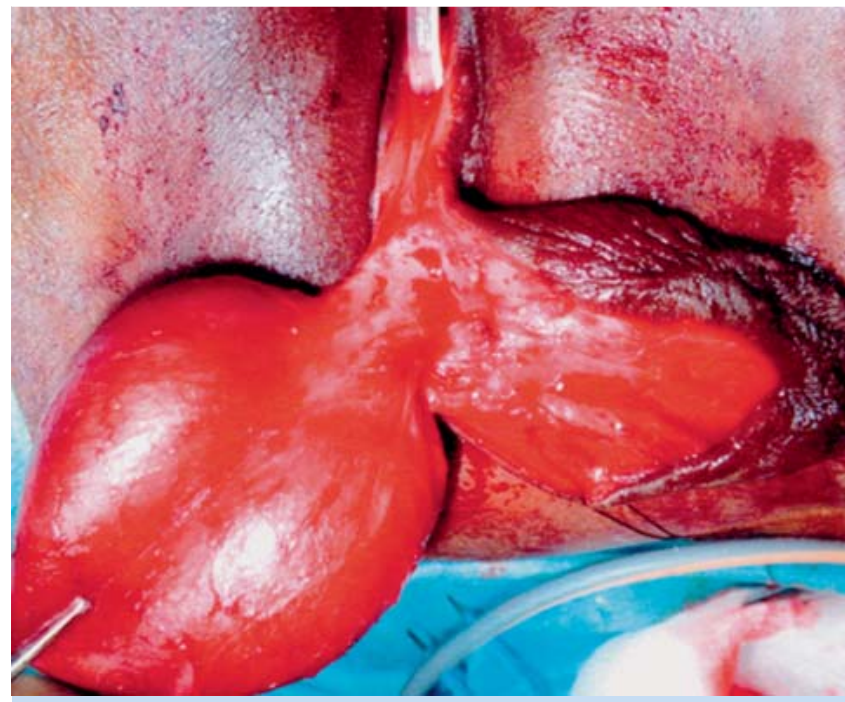

Fig. 3 Squamous epithelial cyst with scar tissue stalk (peduncle) after complete marsupialisation, intraoperative picture.

[12]. Gudu et al. present a case comparable to ours in BMC Women's Health Journal [7]: A 21-year-old woman who had undergone infibulation at the age of 8 years presented to them with a painful, infected swelling in the vulvar area. Complete surgical excision of a cyst and simultaneous defibulation were performed. There were no subsequent complications.

Squamous epithelial inclusion cysts and dermoid cysts in the vulvar area are extremely rare and occur as complications of FGM, episiotomy or other local trauma to the vulva $[7,8,13]$. The usually painless and progressively enlarging cysts arise through invagination and entrapment of squamous epithelium, other cell remnants and secretions in scar tissue beneath the skin surface. Incidence and latency following FGM is variable. Most cysts are asymptomatic but may enlarge. Patients often consult a doctor only when local pain or cyst rupture during sexual intercourse occurs, or at vaginal delivery. Cyst complications include infection, rupture, haematoma or carcinoma. Treatment of choice is complete removal of the cyst and, if necessary and possible, simultaneous plastic surgical reconstruction of the genitalia [7]. Different reconstructive options apply to the different forms of FGM ( Table 1). Here P. Foldès must be mentioned, whose retro-

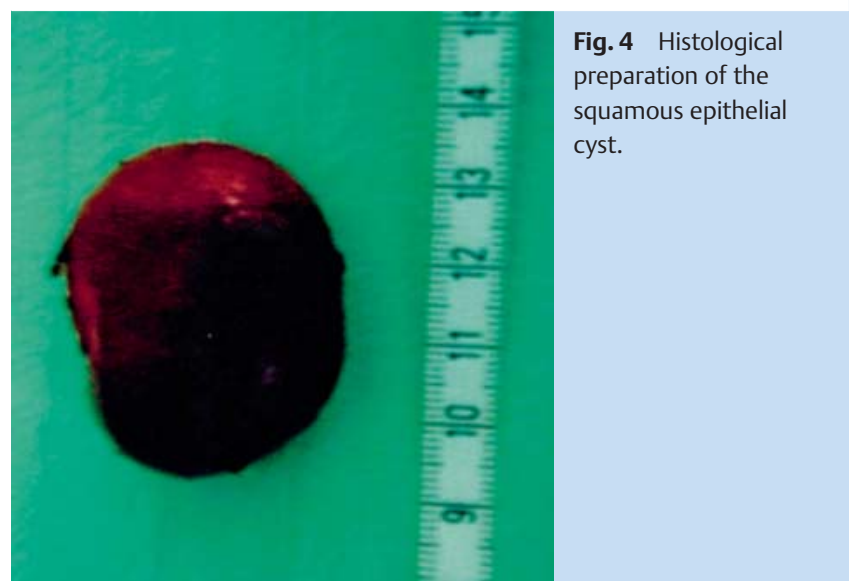


Table 1 WHO classification of FGM.

\begin{tabular}{|c|c|c|}
\hline Type 1 & Sunna & $\begin{array}{l}\text { Excision of the clitoral hood with partial } \\
\text { or complete removal of the clitoris }\end{array}$ \\
\hline Type 2 & $\begin{array}{l}\text { Excision, } \\
\text { clitoridectomy }\end{array}$ & $\begin{array}{l}\text { The clitoris is completely removed, } \\
\text { the labia minora partially or totally re- } \\
\text { moved, the vaginal orifice is not closed. }\end{array}$ \\
\hline Type 3 & Infibulation & $\begin{array}{l}\text { Complete removal of the clitoris and labia } \\
\text { minora, partial removal of the labia majora } \\
\text { by detachment of their inner edges, the } \\
\text { remaining skin being stitched together so } \\
\text { that a bridge of scar tissue forms over the } \\
\text { vaginal orifice leaving only a small opening } \\
\text { for menstrual blood and urine. }\end{array}$ \\
\hline Type 4 & $\begin{array}{l}\text { Practices not } \\
\text { further classified }\end{array}$ & $\begin{array}{l}\text { Pricking or piercing of the clitoris, tearing, } \\
\text { incising etc. }\end{array}$ \\
\hline
\end{tabular}

spective study presents the results of genital reconstruction in type II and type III FGM in 2938 patients. His preferred surgical method is as follows: The remaining clitoris is exposed by resecting the covering skin. The suspensory ligament of the clitoris is then divided to achieve better mobilization of the stump. The clitoris is then fixed in its correct position in the skin [14]. Many of the above mentioned complications can be partially or completely rectified by defibulation [10].

Through increasing migration more girls and female youths with FGM are likely to present to practices and hospitals in Germany in years to come. According to estimates by Terre de Femmes approx. 18000 girls and women are affected and 5000-6000 are at risk [15]. Clinical experience is generally minimal as demonstrated by Hänselmann et al. [9]. In their study from 2011 only 14 of 223 participating medical practices had treated women with FGM. There were no exact data on affected girls and female youth.

\section{Conclusion}

$\nabla$

Vulvar epithelial inclusion cysts and dermoid cysts following FGM are extremely rare. Complications often require surgical intervention. Through increasing migration, more girls and female youths with FGM are likely to present to practices and hospitals in Germany. Thus increased knowledge and awareness of the medical complications of FGM and their treatment is necessary.

\section{Conflict of Interest}

None.

\section{References}

1 Dettmeyer R, Laux J, Friedl H et al. Medizinische und rechtliche Aspekte der Genitalverstümmelung bzw. Beschneidung. Archiv für Kriminolologie 2011; 227: 1-22

2 Knight M. Curing cut or ritual mutilation? Some remarks on the practice of female and male circumcision in Graeco-Roman Egypt. Isis 2001; 92: 317-338

3 Female genital mutilation. Online: https://en.wikipedia.org/wiki/ Female_genital_mutilation; last access: 22.06.2015

4 Rodriguez SW. Rethinking the history of female circumcision and clitoridectomy: American medicine and female sexuality in the late nineteeth century. J Hist Med Allied Sci 2008; 63: 323-347

5 Herrmann B, Dettmeyer R, Banaschak S et al. Kindesmisshandlung, medizinische Diagnostik, Intervention und rechtliche Grundlagen. Kapitel 6.6. 2. aktualisierte Aufl. Heidelberg: Springer; 2010: 104-109

6 Plo K, Asse K, Seï D et al. Female genital mutilation in infants and young girls: report of sixty cases observed at the general hospital of abobo (abidjan, cote d'ivoire, west Africa). Int J Pediatr 2014; 2014: 837471

7 Gudu W. Acute vulvar pain in a lady with post circumcision inclusion cyst of the vulva containing stones: a case report. BMC Womens Health 2014; $14: 2$

8 Rizk DE, Mohammed KH, Joshi SU et al. A large clitoral epidermoid inclusion cyst first presenting in adulthood following childhood circumcision. J Obstet Gynecol 2007; 27: 445-448

9 Hänselmann K, Börsch C, Ikenberg $H$ et al. Weibliche Genitalverstümmelung in Deutschland. Geburtsh Frauenheilk 2011; 71: 205-208

10 Teufel K, Dörfler DM. Female genital circumcision/mutilation: implications for female urogynaecological health. Int Urogynecol J 2013; 24: 2012-2027

11 Deutsche Gesellschaft für Gynäkologie und Geburtshilfe. Empfehlung zum Umgang mit Patientinnen nach weiblicher Genitalbeschneidung/ Genitalverstümmelung. ZB MED, Frauenarzt 2012; 53: 277-283

12 Berg RC, Denison E. Does female genital mutilation/cutting (FGM/C) affect women's sexual functioning? A systemic review of the sexual consequences of FGM/C. Sex Res Soc Policy 2012; 9: 41-56

13 Kroll GL, Miller L. Vulvar epithelial inclusion cyst as a late complication of childhood female traditional genital surgery. Am J Obstet Gynecol 2000; 183: 509-510

14 Foldès $P$. Reconstructive surgery after female genital mutilation: a prospective cohort study. Lancet 2012; 380: 134-141

15 Terre de Femmes. TDF veröffentlicht EU-Studie zur Genitalverstümmelungen, Pressemitteilung, 2005. Online: http://web.archive.org/web/ 20081211075638/http://www.frauenrechte.de/tdf/index.php?option =com_content\&task=view\&id=325\&Itemid=82; last access: 21.06 .2015 